\title{
PTFI Big Gossan Mine - Ventilation Design to Support the New Stope Sequence Strategy
}

\author{
Z Diaz ${ }^{1}$, E Sulistiyo ${ }^{2}, \mathrm{R} \mathrm{Sani}^{3}$ \\ PT. FREEPORT INDONESIA
}

\begin{abstract}
Big Gossan (BG) mine is an open stope mine operated by PT Freeport Indonesia (PTFI). This mine started its development in 2006. Currently, the mine consists of 9 active levels, each level is designed with about $1 \mathrm{~km}$ footwall drift East-West. The production initiated in 2009 , but the mine was temporarily shut down due to a company decision. Lately the mine has been re-activated since 2017 and will be pushed into its peak production in 2019, with 7000 tpd production rate. In order to meet with the production goal, 5 levels consisting of 34 at least production stopes are required on a yearly basis. The other strategy to meet the production goal is an improvement of stopes sequencing. Big Gossan Mine is ventilated by two parallel $1600 \mathrm{~kW}$ exhaust Mixed-Flow fans.
\end{abstract}

This paper presents the ventilation plan and design to support the improved stope sequence until peak production, include the analysis of ventilation design criteria, ventilation network modeling, infrastructure required, possibility of main fans upgrade and other ventilation open stope mine challenges.

\section{INTRODUCTION}

Big Gossan Mine is being operate by PT Freeport Indonesia an affiliate of Freeport McMoRan. The deposit is a part of the East Ertsberg Skarn System (EESS) ore body, located within the underground mining complex of PTFI, which is about 100 $\mathrm{km}$ north of the southwest coast of Papua, Indonesia between $2510 \mathrm{~m}$ and $3180 \mathrm{~m}$ above sea level.

PTFI's underground mines are DOZ Mine, DMLZ Mine, Big Gossan Mine and Grasberg Block Cave Mine (GBC). All of these mines are block cave operations with the exception of the Big Gossan Mine, which is an open stope mine. The Grasberg Block Cave mine will eventually replace the Grasberg Open Pit Mine.

In term of the mine production DOZ mine production rate is $35.000 \mathrm{tpd}$, BG mine peak production is forecasted at 7.000 tpd. DMLZ mine peak production is forecasted at 80.000 tpd capacity. GBC mine peak production is $130.000 \mathrm{tpd}$. 


\section{BIG GOSSAN MINE OVERVIEW}

Big Gossan mine main levels are located at $2510 \mathrm{~m}$ until $3180 \mathrm{~m}$ above sea level. There are multiple main access from the surface; the upper levels can be accessed through the Amole Tunnel, Aghawagon Tunnel \& ARD Tunnel, the middles level from the Kasuang Tunnel and the lower levels from AB Tunnel. The levels are connected by an Inter-level ramp, which is the only equipment access for this open stope mine. See figure 1 for the detail.

BG Mine ore management is delivered from each level via nine-ore passes, down to 2540 Haulage Level. Elphinstone AD 55 trucks are loading the ore from the loading points to BG Crusher at $2510 \mathrm{~L}$ via a grizzly. An ore-bin is collected the ore before it delivered up via the two cages 500m-shaft production to upper conveyor system out to the mill. A lower conveyor system is connecting the orebin and the shaft production.

To support the mine operations some fixed facilities have constructed in underground. Heavy equipment shops constructed at 2510L include all main BG Offices, to do heavy equipment PM \& repair. Batch plant constructed at $3100 \mathrm{~L}$, a facility to feed paste fill activities. Magazine constructed at 2860L. In term of ventilation support, those facilities have its dedicated ventilation system; the airflow dedicated for those facilities are directly exhausted to the exhaust connections, so those are not delivered for the other activities as re-used air.

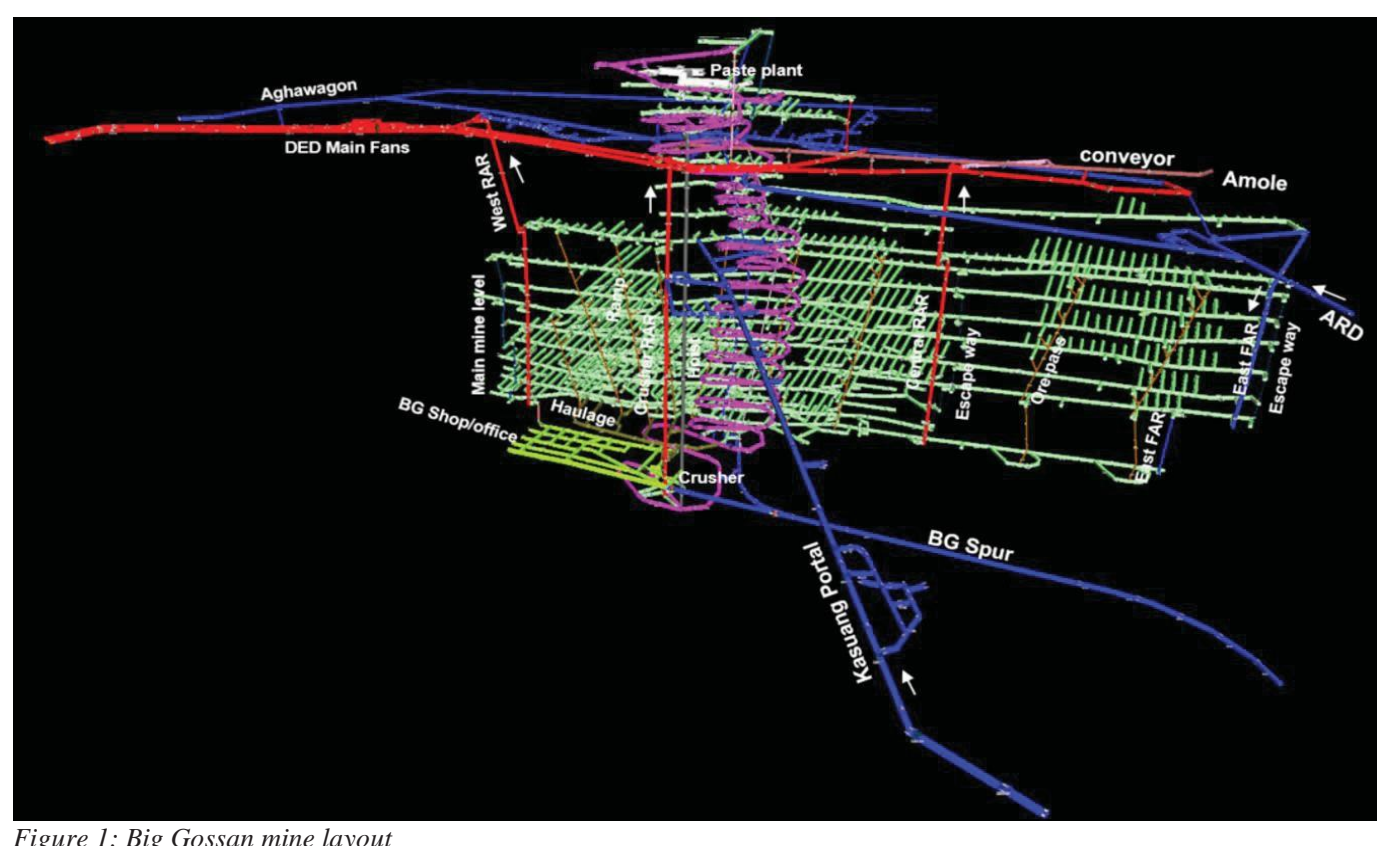

Figure 1: Big Gossan mine layout

\section{BIG GOSSAN MINE VENTILATION SYSTEM}

The current Big Gossan mine primary ventilation Infrastructure consists of: 
- 2 x $1600 \mathrm{~kW}$ HOWDEN $3500 \mathrm{~mm}$ mixed-flow fans

Intake ventilation system:

- Kasuang Tunnel $6 \mathrm{~m}$ x $6 \mathrm{~m}$ drift

- ARD tunnel $5.5 \mathrm{~m} \times 5.5 \mathrm{~m}$ drift

- Aghawagon tunnel $5.5 \mathrm{~m}$ x $5 \mathrm{~m} \mathrm{drift}$

- Amole Tunnel $5 \mathrm{~m} \mathrm{x} 4.5 \mathrm{~m}$ drift

- Fresh Air Raise (FAR) 4 m diameter (raise bore) with a connection at each level

- Inter-level ramp $6.5 \mathrm{~m}$ x $6 \mathrm{~m}$ drift

Exhaust ventilation system:

- Dedicated Exhaust Drift \#1 $6.5 \mathrm{~m}$ x 5.5m

- Dedicated Exhaust Drift \#2 $6.5 \mathrm{~m}$ x 5.5m

- West Return Air Raise (WRAR) and Central Return Air Raise (CRAR) 6 m diameter connected to each level

- Crusher Return Air Raise (CRAR) for crushing plant area 4 m diameter

VENTILATION DESIGN TO SUPPORT THE NEW STOPE SEQUENCE

Since the mine has re-activated lately, a new mine strategy was implemented. This new plan is more aggressive compare to the old plan specially for the mid and east ore body. The change's trigger is the stope sequence for mid and east ore-body, while the west ore-body remain at the same sequence. The differences are increasing the stope active plans each levels and it also affect to development expansions to prepare the stopes.

It is shown in figure $2 \& 3$ below the mine operation plan comparison. From figure 2 , it can be configured that each level activities will be multiplied; stope productions will set $6-8$ stopes active both middle and east block ore-body. Which at the same time drift development also still need to be conducted at the same level. In figure 3 , it is shown the production tonnage and meter drift development difference between the old and new plan.

The new stope sequence ventilation design for middle and east block ore-body set as different ventilation segment to avoid series auxiliary ventilation system; so reuse air is not applicable. This requirement has increased Big Gossan mine airflow budget. 

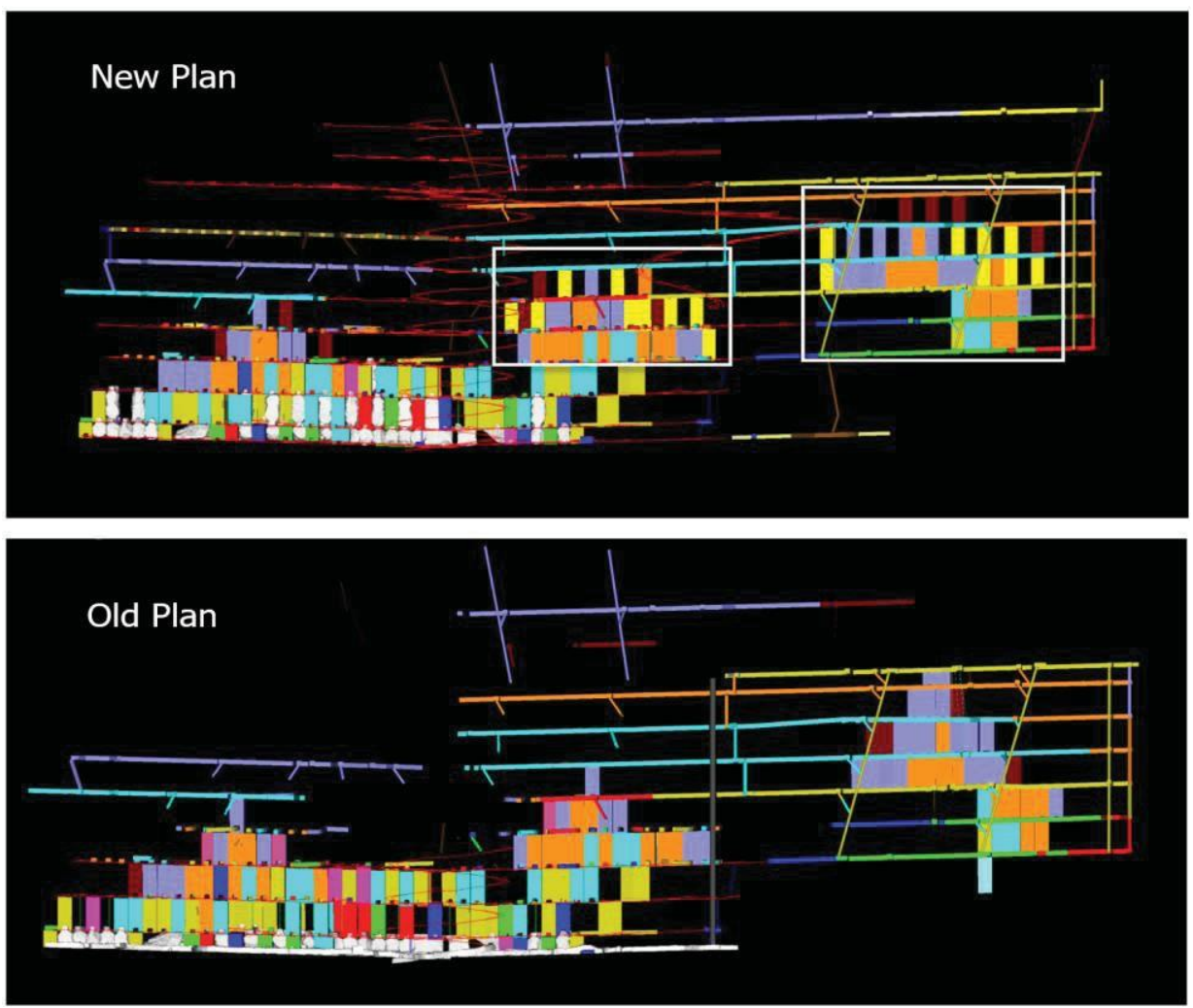

Figure 2: Big Gossan Old VS New Plan comparison

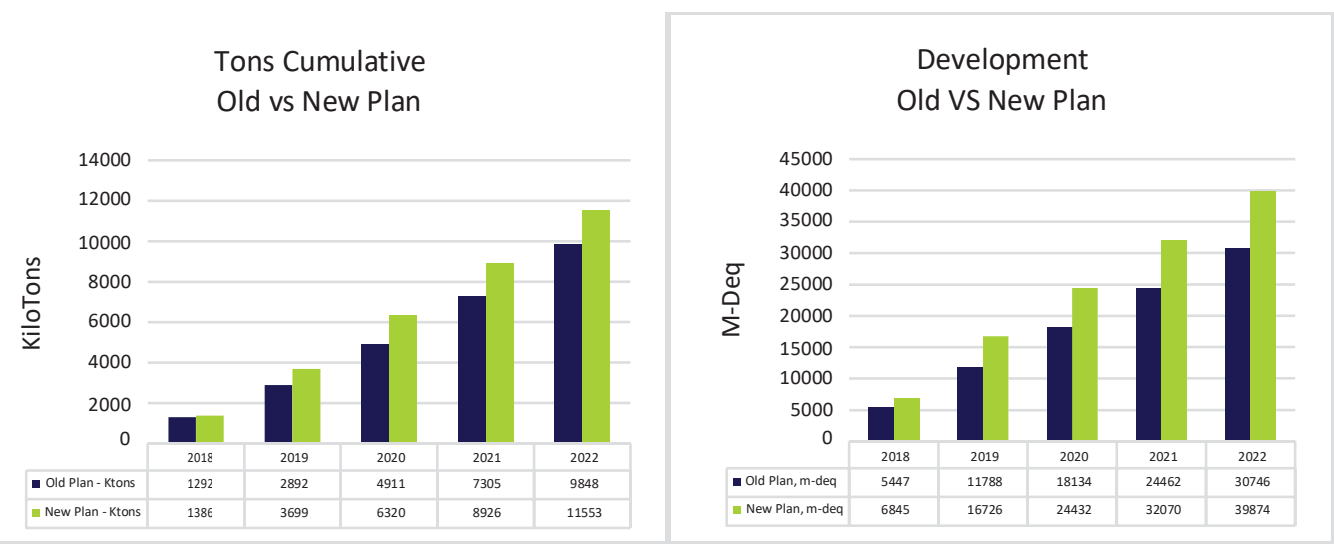

Figure 3: Big Gossan Old VS New Plan tons production and m development numbers comparison

\section{Ventilation Design Criteria}

PTFI has created a design criteria document that is used to determine airflow requirements for various activities. The criteria was created with a combination of international best practices, and the Decree of the minister of Mines and Energy requirements, whichever is more protective. The Ventilation design criteria is a guidance to build ventilation model and to calculate basic ventilation requirement at each work location. When performing more detailed analysis of a specific area, a consideration for heading fan recirculation must also be made, there must be enough airflow to prevent heading fan recirculation, even if there is a low amount of activity in a given area. 


\section{Total Airflow Budget}

Total airflow budget is calculated by two different method. The first method is calculating all diesel engines applied in Big Gossan. As shown in Table 1. Airflow requirement for all diesel engine fleet include leakage $15 \%$ is $549 \mathrm{~m}^{3} / \mathrm{s}$. For all fixed facilities set at $194 \mathrm{~m}^{3} / \mathrm{s}$. So totally BG need $743 \mathrm{~m}^{3} / \mathrm{s}$.

Table 1: Big Gossan mine airflow requirement based-off of the equipment availability

\begin{tabular}{|c|c|c|c|c|c|c|}
\hline Equipment & Utilization Factor (\%) & $\begin{array}{l}\text { Unit Power } \\
\text { (Horse Power) }\end{array}$ & $\begin{array}{l}\text { Unit Power } \\
\text { (kilo Watt) }\end{array}$ & $\begin{array}{c}\text { Airflow } \\
\text { Per unit } \\
\left(\mathrm{m}^{3} / \mathrm{s}\right)\end{array}$ & $\begin{array}{c}\text { equipment } \\
\text { QTY }\end{array}$ & $\begin{array}{c}\text { Total } \\
\text { Airflow } \\
\left(\mathrm{m}^{3} / \mathrm{s}\right)\end{array}$ \\
\hline Cabolter & 50 & 149 & 111 & 4.4 & 2 & 9 \\
\hline Axera 7 & 50 & 149 & 111 & 4.4 & 6 & 27 \\
\hline Commando 120 & 50 & 111 & 83 & 3.3 & 2 & 7 \\
\hline Solo Drill & 50 & 60 & 45 & 3.6 & 4 & 14 \\
\hline Elphinestone R1300 & 80 & 123 & 92 & 5.9 & 1 & 6 \\
\hline Elphinestone R1600 & 100 & 270 & 201 & 16.1 & 2 & 32 \\
\hline Elphinestone R1700 & 100 & 310 & 231 & 18.5 & 8 & 148 \\
\hline Elphinestone AD30 & 80 & 400 & 298 & 19.1 & 4 & 76 \\
\hline Elphinestone AD55 & 80 & 650 & 485 & 31.0 & 2 & 62 \\
\hline Boom Truck & 50 & 81 & 60 & 2.4 & 2 & 5 \\
\hline Getman Flatbed Truck & 30 & 130 & 97 & 2.3 & 3 & 7 \\
\hline Getman Mixer Truck & 50 & 154 & 115 & 4.6 & 3 & 14 \\
\hline Scissor Truck & 30 & 81 & 60 & 1.4 & 2 & 3 \\
\hline Western Star/Isotainer Truck & 30 & 380 & 283 & 6.8 & 1 & 7 \\
\hline Backhoe & 30 & 82 & 61 & 1.5 & 3 & 4 \\
\hline Grader & 30 & 93 & 69 & 1.7 & 2 & 3 \\
\hline Shotcrete Sprayer & 50 & 154 & 115 & 4.6 & 3 & 14 \\
\hline Water Canon & 30 & 80 & 60 & 1.4 & 1 & 1 \\
\hline Telehandler & 30 & 78 & 58 & 1.4 & 3 & 4 \\
\hline Iveco Bus & 30 & 380 & 283 & 6.8 & 2 & 14 \\
\hline Isuzu Manhaul & 30 & 43 & 32 & 0.8 & 3 & 2 \\
\hline Personel vehicles & 30 & 43 & 32 & 0.8 & 8 & 6 \\
\hline \multicolumn{6}{|l|}{ Subtotal Mobile Equipment } & 465 \\
\hline Personnel & & & & 0.03 & 400 & 12 \\
\hline \multicolumn{6}{|c|}{$15 \%$ of leakages } & 72 \\
\hline \multicolumn{6}{|c|}{ Total Airflow Requirement } & 549 \\
\hline
\end{tabular}

The second method is based on activity per level. There are 28 segments with 13 development and production activities segments that need to be supported with enough air to prevent heading fan recirculation. There are 15 standby segments (no activity except for inspections and storages), which still need ventilation support based on the minimum velocity allowed based on the design criteria. Totally it needs $999 \mathrm{~m}^{3} / \mathrm{s}$. The second method total airflow is used to define Big Gossan mine airflow requirement since it is bigger than the first method.

Table 2: Big Gossan mine airflow requirement based-off of activity per level

\begin{tabular}{|c|c|c|c|c|c|c|c|c|}
\hline \multirow{2}{*}{ No. } & \multirow{2}{*}{ Activities } & \multirow{2}{*}{ Level } & West RAR & Central RAR & East FAR & Balancing & $\begin{array}{l}\text { Other Dedicated Exhaust } \\
\qquad\left(M^{\wedge} \mathbf{3} / \mathrm{S}\right)\end{array}$ & \multirow[t]{2}{*}{ Note } \\
\hline & & & $M^{\wedge} 3 / \mathbf{s}$ & $M^{\wedge} \mathbf{3} / \mathbf{s}$ & $M^{\wedge} 3 / \mathrm{s}$ & $M^{\wedge} 3 / \mathbf{s}$ & & \\
\hline \multirow{11}{*}{1} & \multirow{11}{*}{$\begin{array}{l}\text { Development } \\
\text { \& Production } \\
\text { Level }\end{array}$} & $2940 \mathrm{~L}$ & $\cdot$ & 15 & 15 & & & (min drift velocity, $5.5 \mathrm{~m} \times 5.5 \mathrm{~m} \times 0.5 \mathrm{~m} / \mathrm{s} \rightarrow>15$ ) \\
\hline & & $2900 \mathrm{~L}$ & $\cdot$ & ?. & . & & . & in progress to BT the exhaust raise \\
\hline & & $2860 \mathrm{~L}$ & 15 & 15 & 35 & & - & (min drift velocity, $5.5 \mathrm{~m} \times 5.5 \mathrm{~m} \times 0.5 \mathrm{~m} / \mathrm{s} \rightarrow>15)$ \\
\hline & & $2840 \mathrm{~L}$ & $\cdot$ & 15 & 35 & & . & (min drift velocity, $5.5 \mathrm{~m} \times 5.5 \mathrm{~m} \times 0.5 \mathrm{~m} / \mathrm{s} \rightarrow>15)$ \\
\hline & & $2800 \mathrm{~L}$ & 35 & 15 & 35 & & . & . \\
\hline & & $2760 \mathrm{~L}$ & 35 & 15 & 35 & & . & . \\
\hline & & $2720 \mathrm{~L}$ & 15 & 15 & 35 & & . & (min drift velocity, $5.5 \mathrm{~m} \times 5.5 \mathrm{~m} \times 0.5 \mathrm{~m} / \mathrm{s} \rightarrow>15)$ \\
\hline & & $2680 \mathrm{~L}$ & 35 & 15 & 35 & & . & . \\
\hline & & $2640 \mathrm{~L}$ & 35 & 15 & 15 & & . & (min drift velocity, $5.5 \mathrm{~m} \times 5.5 \mathrm{~m} \times 0.5 \mathrm{~m} / \mathrm{s} \rightarrow>15)$ \\
\hline & & $2600 \mathrm{~L}$ & 15 & 15 & . & & . & not BT to ERAR, '(min drift velocity, $5.5 \mathrm{~m} \times 5.5 \mathrm{~m} \times 0.5 \mathrm{~m} / \mathrm{s} \rightarrow>15)$ \\
\hline & & $2560 \mathrm{~L}$ & 15 & 15 & . & & . & not BT to ERAR, "(min drift velocity, $5.5 \mathrm{~m} \times 5.5 \mathrm{~m} \times 0.5 \mathrm{~m} / \mathrm{s} \rightarrow>15$ ) \\
\hline \multirow{6}{*}{2} & \multirow{6}{*}{ Commitment } & $2540 \mathrm{~L}$ & 35 & 50 & . & & 30 & use $150 \mathrm{HP}$ fan + bulkhead for $L P 08-09$ activity to CRAR $\Phi 6 \mathrm{~m}+$ stby are from west side segment \\
\hline & & $3180 \mathrm{~L}$ & 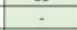 & . & - & & 12.5 & RAR to DED (min drift velocity, $5 \mathrm{~m} \times 5 \mathrm{~m} \times 0.5 \mathrm{~m} / \mathrm{s} \rightarrow>12.5$ ) \\
\hline & & 3100 & $\cdot$ & - & . & & 12.5 & RAR to DED (min drift velocity, $5 \mathrm{~m} \times 5 \mathrm{~m} \times 0.5 \mathrm{~m} / \mathrm{s} \rightarrow>12.5$ ) \\
\hline & & $3060 \mathrm{~L}$ & . & . & . & & 12.5 & RAR to DED (min drift velocity, $5 \mathrm{~m} \times 5 \mathrm{~m} \times 0.5 \mathrm{~m} / \mathrm{s} \rightarrow>12.5$ ) \\
\hline & & $2510 \mathrm{~L}$ & 61 & . & . & & 35 & other: jaw crusher chamber to Crusher RAR \\
\hline & & $3040 \mathrm{~L}$ & . & . & . & & 60 & other: to RAR 1 \& RAR2 conveyor 523.524 \\
\hline \multicolumn{3}{|c|}{ Total } & 296 & 185 & 225 & & 163 & 869 \\
\hline & & & & 15\% Leaka & & & & 999 \\
\hline
\end{tabular}

3. Typical Ventilation Design of each Level Production and Development 
Every level airflow distribution designed based on segmental of the level. Since Big Gossan ore body is not a massive solid from west to east, the airflow distribution is divided to three blocks; west block, middle block and east block. West block in some levels has two different blocks, south and north blocks. It is not allowed to have two blocks as a series ventilation to minimize air contaminant exposure to the downstream block. See figure 4 for the detail, it is shown typical 4 segments in a level.

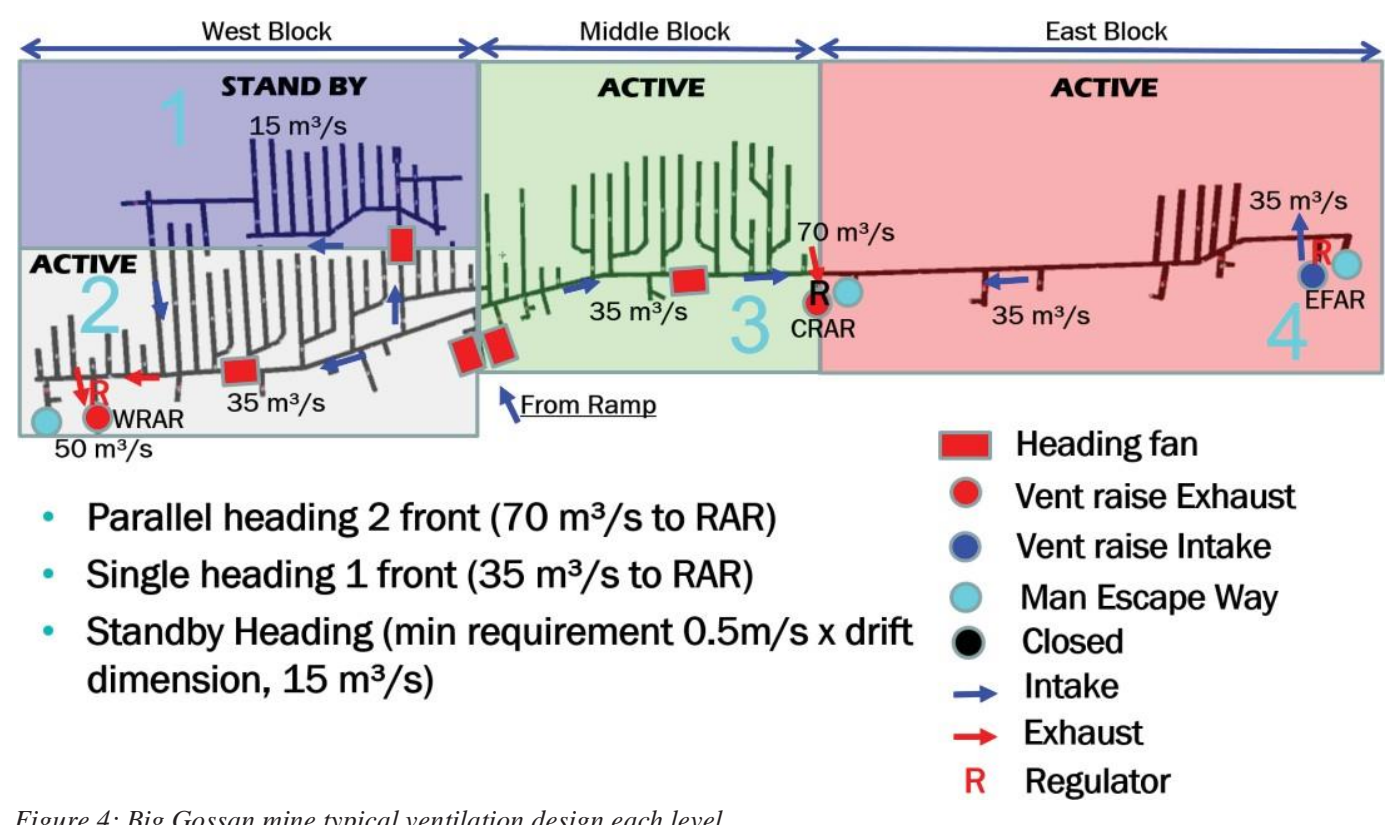

Intake for each level are coming from ramp and East Fresh Air Raise (EFAR), and the exhaust are going to West Return Air Raise (WRAR) and Central Return Air Raise (CRAR). Each level equip with $150 \mathrm{HP}$ fan capacity $(30-35 \mathrm{~m} / \mathrm{s})$ to support $2-3$ heading maximum. Figure 5 is shown of a $150 \mathrm{HP}$ fan general arrangement.

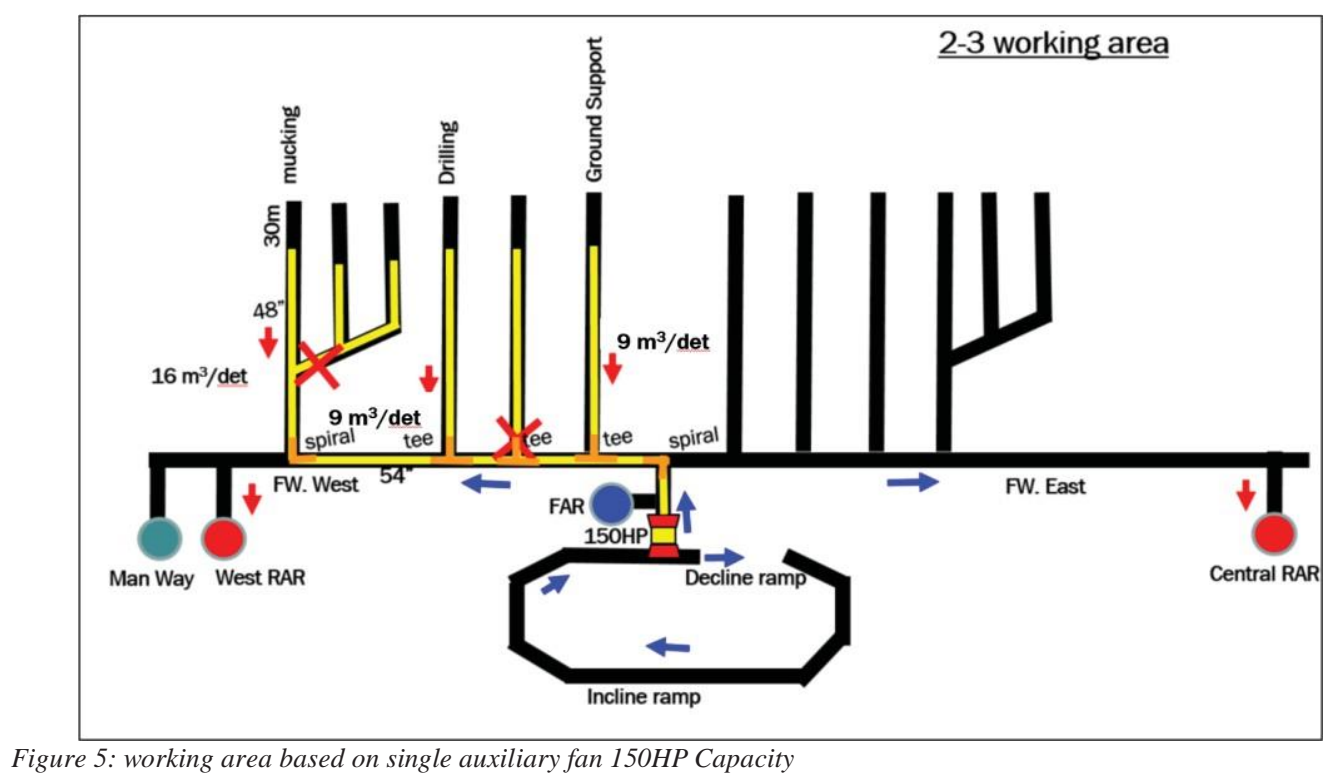




\section{Ventilation Model}

This section of the paper shows the ventilation network model used to deliver the airflow into each active mining area and fixed facilities. The airflow required for each area was determined using the proper calculation from the design criteria. Figure 6 shows the mine ventilation schematic for the Big Gossan mine.

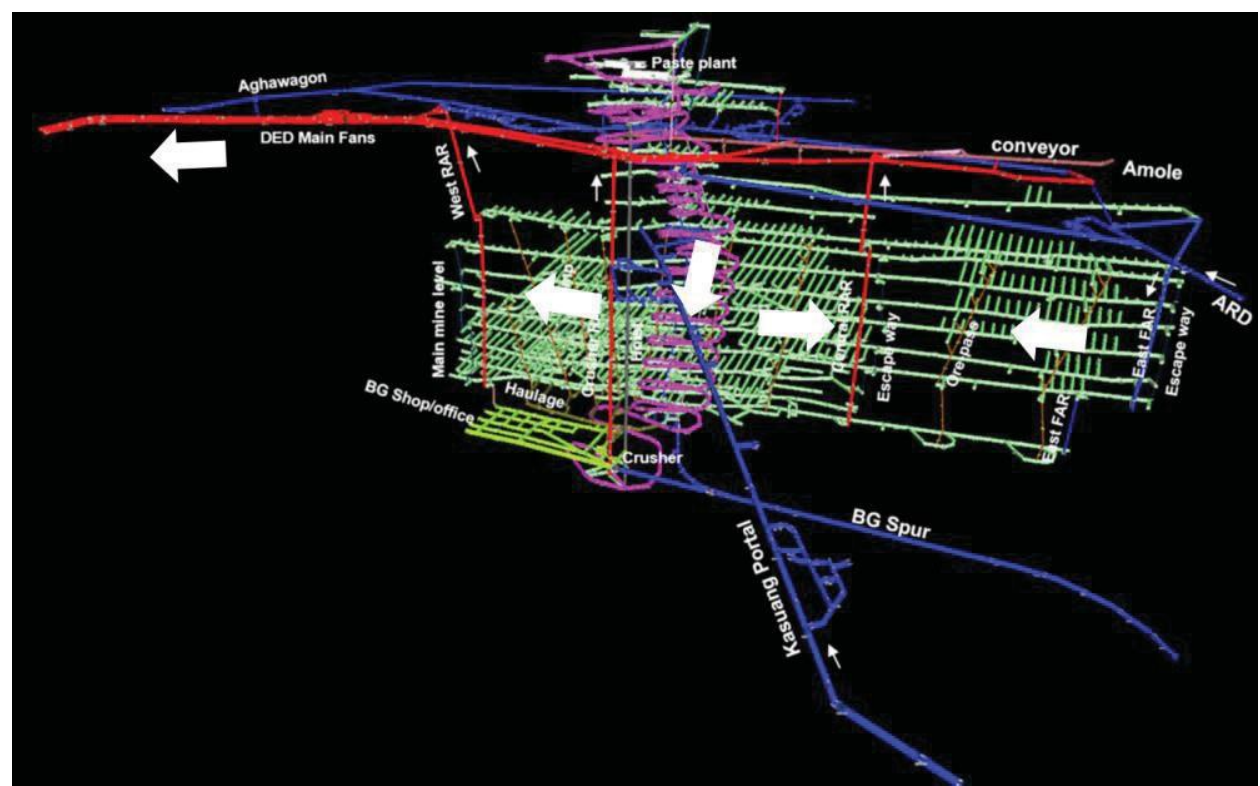

Figure 6: Big Gossan mine ventilation schematic

\section{DISCUSSION}

\section{Main Fans Upgrade}

Since the total airflow requirement is $999 \mathrm{~m}^{3} / \mathrm{s}$, the current $1600 \mathrm{~kW}$ mixed flow fans could not handle it. The operating point is at $460 \mathrm{~m}^{3} / \mathrm{s}$, at $2.0 \mathrm{kPa}$. Currently PTFI has upgraded 3 x DMLZ Main Fans from 2100kW motor to $4100 \mathrm{~kW}$ motor. There is an opportunity to use ex DMLZ 2100kW fan motor for Big Gossan Main Fans.

Applying those main fans at $-25^{\circ} \mathrm{RVC}$ (Radial Vane Control) will produce $500 \mathrm{~m}^{3} / \mathrm{s}$ airflow at $2.4 \mathrm{kPa}$ Total Pressure, which is match with the new design requirement. 


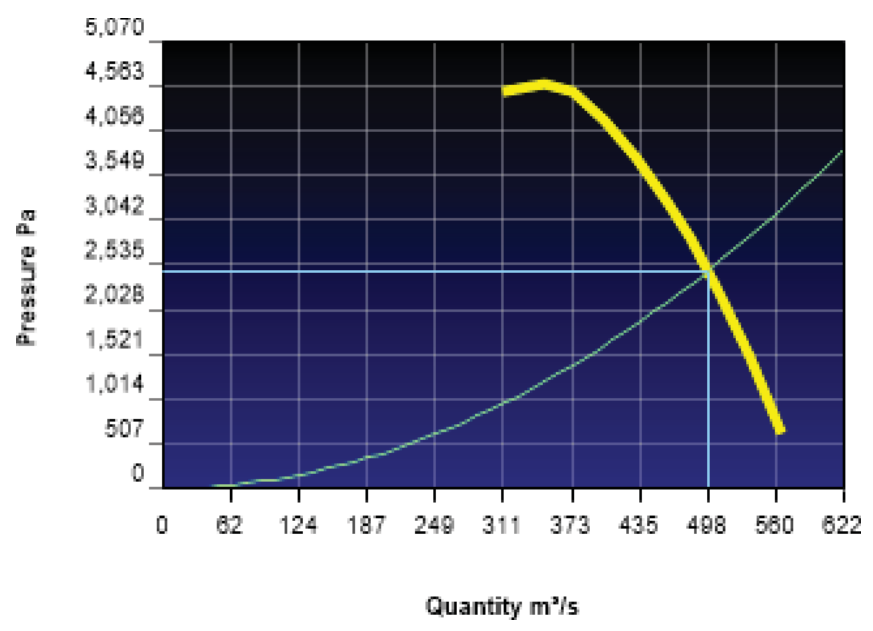

Figure 6: Big gossan main fan operating point

\section{East Fresh Air Raise (EFAR) or East Return Air Raise (ERAR)}

Currently in Big Gossan feasibility study the last east side raise is functioned as Return Air Raise, 6m diameter. Based on the new stope sequence, it is indicated there will be multi activities at middle and east blocks, it could be $2-4$ headings or stopes active. If the raise is applied for ERAR, those two blocks will be designed only single segment ventilation, it means east block will apply re-use air.

The raise diameter should be remain at $6 \mathrm{~m}$ diameter since the current $4 \mathrm{~m}$ diameter Fresh Air Raise (FAR) only can support 4 levels maximum with total air about 120 $\mathrm{m}^{3} / \mathrm{s}$. The raise will need to support 9 levels.

The other EFAR advantages are related with Big Gossan mine ventilation intake source, Big Gossan will have two different sources, from Kasuang Drift via ramp and ARD Portal via EFAR. It will give better air quality since only ARD drift traffic will contaminate the air. In term of mine fire, if one of the intake contaminated, the other intake will not, in a multi-levels mine it is an important advantage.

The air velocity at $2860 \mathrm{~L}$ ramp down to below level will at $13.8 \mathrm{~m} / \mathrm{s}$ with the implementation of ERAR, it is above the internal PTFI design criteria for the main primary intake should maximum $10.2 \mathrm{~m} / \mathrm{s}$. By building EFAR it will decrease air velocity to $10.0 \mathrm{~m} / \mathrm{s}$. High air velocity in a drift may become the issue of uncomfortless working environment and may trigger dust un-settled which creates continuous dust source in the main intake.

\section{Ventilation Management System (VMS)}

A remote or manual VMS is also important to be implemented, similar with DMLZ and GBC Mines. VMS sets are at least consists of :

- Motorized damper in all RAR and FAR connections to the levels, currently at least 3 connections were equipped with it

- Fixed gas detectors - at least with $\mathrm{CO}-\mathrm{NH}_{3}-\mathrm{SO}_{2}$ sensors

- Pressure transmitters 
- A robust network communication

To manage each segment meet its requirement need a big flexibility, with 9 - active levels, total Big Gossan will have totally 28 segments; and only about 13 segments active every shift need to be managed. The airflow budget set is only to support those 13 segments actives and the other 25 segments stand by.

The other VMS opportunities are also be able to shorten blasting smoke clearing and during a main fan regular preventive maintenance, the mine will only support by one fan for one shift. VMS will help to maximize the available airflow to support a few critical segments.

\section{Leakages at interconnection levels}

Leakage via interconnection level is always become the most critical ventilation controls to be monitored. Currently the concerns are open ore pass finger raises, open slot raises and open stopes. Sometimes it will affect to recirculation between levels and caused the blasting smoke clearing take hours. Figure 7 is shown a typical type of leakage control at ore pass. Leakage via stope connection is the next challenge since the access is required for some utilities and just at a blasting location.

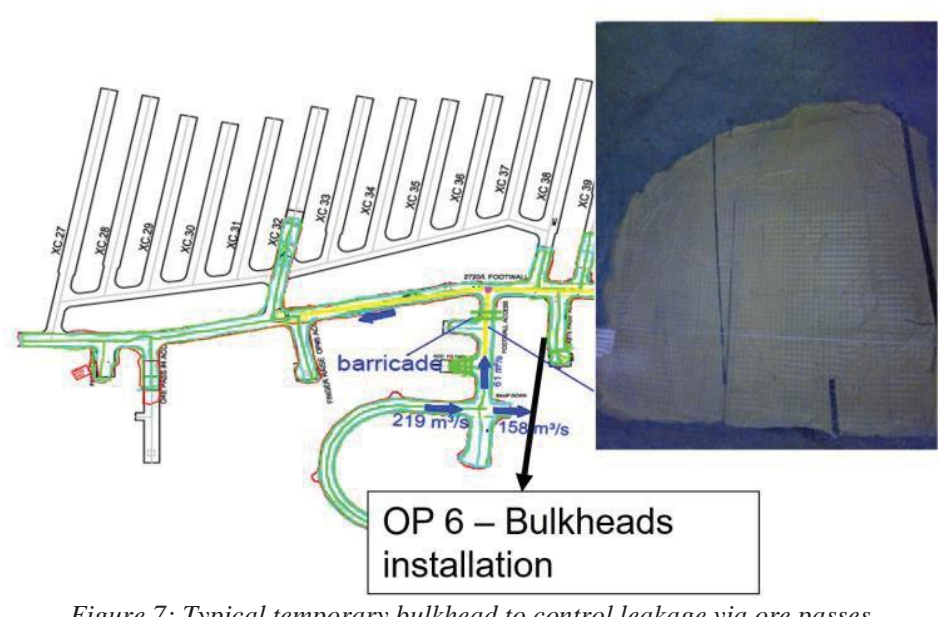

\section{Dust}

Dust is also a significant concern in Big Gossan. Both personal and area sampling have conducted to monitor dust exposure in Big Gossan mine. The dust source are stope activities - after blasting - during mucking and loading; road - along foot wall drift or ramp when floor were dry; ore passes; grizzlies - crushers - conveyors. Currently the mitigation have applied are watering blasting stack muck - watering muck in the stope after blasting from top - installing water spray at the lower stope access - chute LP and along conveyor. In the future wetting floor in all active area with dust suppressant agent is also become the alternative. Figure 8 is shown the 
current dust control implemented.

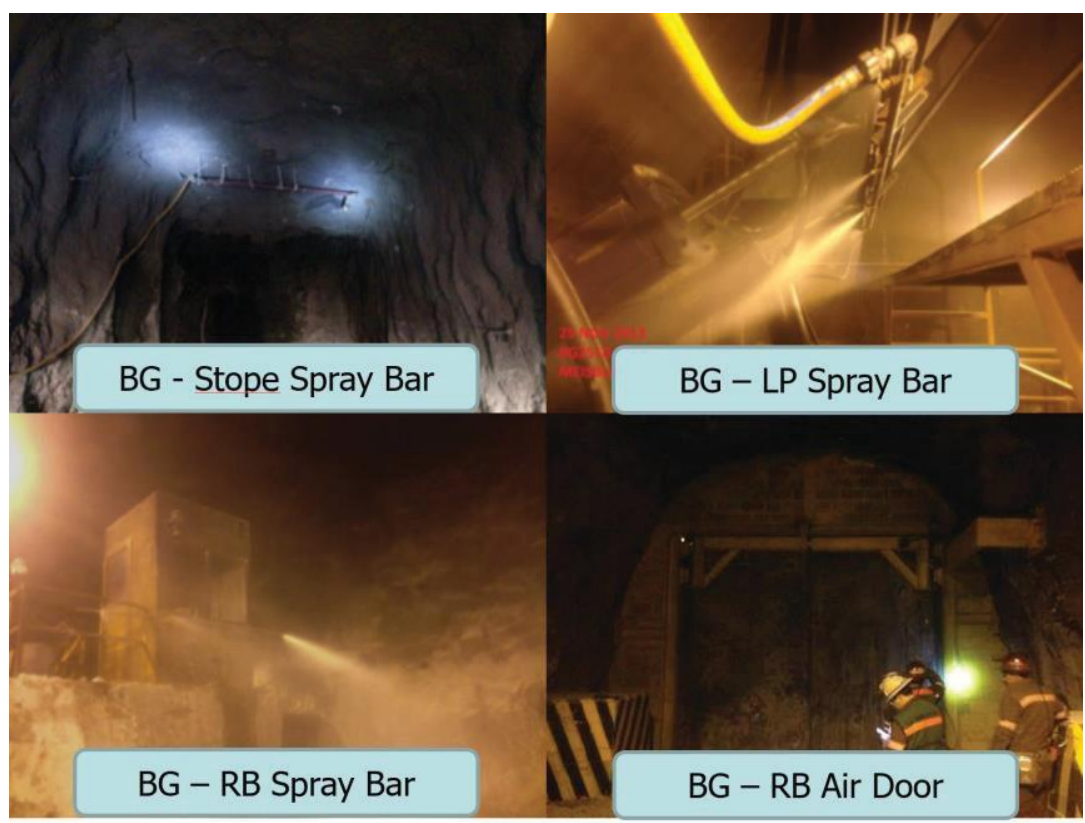

Figure 8: Typical dust controls

\section{CONCLUSION}

PTFI are moving forward with construction of a modern, large open stopping operation requiring a relatively complex ventilation system. In order to support Big Gossan mine new stope sequence, PTFI Management need to consider to analyze more on the three suggested new ventilation recommendation. Firstly, main fans upgrade to accommodate the new airflow budget. Secondly, building an EFAR than an ERAR to support mid and east blocks with better ventilation system, which also includes several advantages relate with mine emergency response and better air quality intake to the mine. Thirdly, VMS implementation to give mine ventilation operation flexibility; real-time air quantity and quality monitoring include possibility to also give more advantages on mine emergency response.

At the other sides, as the common concerns of an open stope mine leakages at interconnection levels and dust management system still become continuous effort to support Big Gossan mine with a good mining practices.

\section{REFERENCES}

Decree of Minister of Mines and Energy Indonesia, 1995, Number 555.K/26/M.PE/1995, General Mining

Freeport McMoRan Copper \& Gold Inc., 2005, Feasibility Study for the Big Gossan Mine, Unpublished report for PT Freeport Indonesia

PT Freeport Indonesia (2014) Ventilation Design Criteria, revision 5, internal document. 
Sani, R.Z., I. Loomis, Sebayang H.Y. (2008) Ventilation Design for the Big Gossan Open Stope Mine, West Papua, Indonesia, in Proceedings, $12^{\text {th }}$ U.S./North American Mine Ventilation Symposium, pp 19-25 (University of Nevada Reno)

PT Freeport Indonesia (2018) 18Q3R0 Aggressive Plan Presentation, internal document. 
